\title{
PENGARUH ENDORPHIN MASSASE TERHADAP RASA NYAMAN SELAMA PROSES PERSALINAN DI PUSKESMAS MAHALONA KABUPATEN LUWU TIMUR Ayu Irawati \\ email irawati01ayu@gmail.com
}

\begin{abstract}
ABSTRAK
Endorphin massage adalah teknik sentuhan dan pijatan, teknik endorphin sangat penting bagi ibu hamil sebab teknik ini dapat membantu memberikan rasa tenang dan nyaman baik disaat menjelang maupun di saat proses persalinan akan berlangsung. Sementara data dari Puskesmas Mahalona jumlah ibu bersalin tahun 2017 jumlah ibu bersalin sebanyak 142 orang, dan data persalinan untuk meringankan nyeri persalinan yang tersedia hanya 2 yakni, tahun 2016 sebanyak dengan teknik birthing ball 53 orang dan tahun 2017 sebanyak 42 orang. Dikembangkan lagi penanganan nyeri persalinan menggunakan kompres air hangat. Sementara ada beberapa orang yang tidak mendapatkan terapi untuk menghilangkan nyeri persalinan maka peneliti tertarik untuk melakukan penelitian dengan judul "pengaruh endorphin massase terhadap rasa nyaman selama proses persalinan di Puskesmas Mahalona Kabupaten Luwu Timur.

Teknik sampling dalam penelitian menggunakan teknik total sampling, berdasarkan ciri-ciri yang telah ditentukan dalam kriteria inklusi sebagai sampel sebanyak 32 ibu inpartu. Analisis yang dilakukan adalah melakukan uji dengan Chi-square.

Berdasarkan hasil penelitian ada pengaruh endorphin massase terhadap rasa nyaman selama proses persalinan yang dibuktikan dengan uji statistik chi square nilai $p$ adalah $0,000(p<0.05)$
\end{abstract}

Kata kunci: Endorphin massase, Rasa nyaman selama proses persalinan 


\section{PENDAHULUAN}

Endorphin massage adalah teknik sentuhan dan pijatan, teknik endorphin sangat penting bagi ibu hamil sebab teknik ini dapat membantu memberikan rasa tenang dan nyaman baik disaat menjelang maupun di saat proses persalinan akan berlangsung. Endorphin sebenarnya adalah sebuah zat di dalam tubuh yang memiliki sekali manfaat adalah gabungan dari endogenous dan morphine, yaitu zat yang merupakan unsure dari protein yang di produksi oleh sel-sl tubuh serta sistem saraf manusia.

Salah satu cara penatalaksanaan nonfarmakologis untuk mengurangi nyeri persalinan dengan endorphine massage. Endorphin Massage merupakan sebuah terapi sentuhan/pijatan ringan yang cukup penting diberikan pada wanita hamil, di waktu menjelang hingga saatnya melahirkan. Hal ini disebabkan karena pijatan merangsang tubuh untuk melepaskan senyawa Endorphin yang merupakan pereda rasa sakit dan dapat menciptakan perasaan nyaman.

Selama ini endorphin sudah dikenal sebagai zat yang banyak manfaatnya. Beberapa diantaranya adalah, mengatur produksi hormon pertumbuhan dan seks, mengendalikan rasa nyeri serta sakit yang menetap, mengendalikan perasaan stres, serta meningkatkan sistem kekebalan tubuh. Endorphin dalam tubuh bisa dipicu munculnya melalui berbagai kegiatan, seperti pernapasan yang dalam dan relaksasi, serta meditasi.

Seorang ahli kebidanan, Constance Palinsky, tergerak untuk menggunakan endorphin untuk mengurangi atau meringankan rasa sakit pada ibu yang akan melahirkan. Diciptakanlah Endorphin Massage, yang merupakan teknik sentuhan serta pemijatan ringan, yang dapat menormalkan denyut jantung dan tekanan darah, serta meningkatkan kondisi rileks dalam tubuh ibu hamil dengan memicu perasaan nyaman melalui permukaan kulit. Terbukti dari hasil penelitian, teknik ini dapat meningkatkan pelepasan zat oksitosin, sebuah hormon yang memfasilitasi persalinan.

Penelitian Insaffitan dengan judul "Pengaruh Massage Punggung Terhadap Nyeri Primigravida Kala I Persalinan Fisiologis (Studi Kasus Di RSAB Gajayana Malang)" mendukung rasa nyeri dapat dikurangi dengan massage. Hasil yang diperoleh rata-rata skala nyeri pada responden sebelum dilakukan massage dan sesudah $92 \mathrm{http}$ :jurnal.unimus.ac.id dilakukan massase adalah berbeda secara signifikan. Rata-rata skala nyeri pada responden sebelum dilakukan massage $(12,31)$ lebih tinggi daripada responden sesudah dilakukan massage $(4,69)$.

Hal ini didukung juga oleh hasil penelitian Marfuah (2010), dengan judul perbedaan intensitas nyeri kala I persalinan normal pada ibu primipara yang diberikan hypnoterapy di BPS Yohana dan Sumarni Semarang. Hasil penelitian menunjukkan bahwa kelompok yang diberi hypnotherapy intensitas nyeri berat $40 \%$, nyeri sedang $53,3 \%$, nyeri ringan $6,7 \%$. Kelompok yang tidak diberi tidak nyeri $66,7 \%$, nyeri sedang $30 \%$, dan nyeri ringan $3,3 \%$.

Data dari Dines Kesehatan Luwu Timur tahun 2015 ibu bersalin sebanyak 6.181 orang, yang ditolong nakes 5.731 dan yang ditolong dukun sebanyak 12 orang, tahun 2016 sebanyak 6.164 ibu bersalin, yang ditolong nakes 5.676 dan yang ditolong dukun sebanyak 16 orang, tahun 2017 jumlah ibu bersalin sebanyak 6.293 orang, yang ditolong nakes 5.719 dan yang ditolong dukun sebanyak 13 orang, meninggal 4 orang.

Sementara data dari Puskesmas Mahalona jumlah ibu bersalin tahun 2015 sebanyak 111 orang, tahun 2016 jumlah ibu bersalin sebanyak 133, tahun 2017 jumlah ibu bersalin sebanyak 142 orang, dan data pijat persalinan untuk meringankan nyeri persalinan yang tersedia hanya 2 yakni, tahun 2016 sebanyak 53 orang dengan teknik birthing ball dan sementara tahun 2017 sebanyak 42 orang. Dikembangkan lagi penanganan nyeri persalinan menggunakan kompres hangat sebanyak 41 orang, birthing ball sebanyak 32 orang, sementara ada beberapa orang yang tidak mendapatkan terapi untuk menghilangkan nyeri persalinan karena ibu menolak melakukannya karena tidak tahan dengan nyeri yang mereka alami.

Berdasarkan uraian diatas, maka peneliti tertarik untuk melakukan penelitian dengan judul Pengaruh endorphin massase terhadap rasa nyaman selama proses persalinan di Puskesmas Mahalona Kabupaten Luwu Timur tahun 2018. 
METODE PENELITIAN

A. Desain Penelitian

Dalam penelitian ini menggunakan desain penelitian Experimental dengan rancangan pretest-posttest design. Pada penelitain responden diberikan perlakuan endorphin massase untuk member rasa nyaman selama proses persalinan .

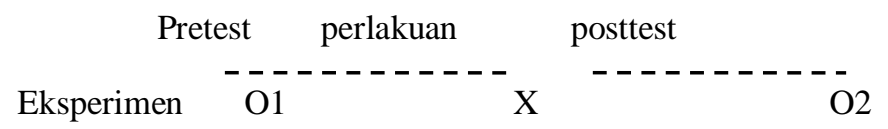

Gambar 3.1 pretest-posttest design

B. Lokasi dan Waktu Penelitian

1. Lokasi Penelitian

Penelitian ini akan dilaksanakan di Puskesmas Mahalona kabupaten Luwu Timur, tahun 2018.

2. Waktu Penelitian

Penelitian ini dilakukan bulan Januari sampai Mei Tahun 2018.

C. Populasi dan Sampel Penelitian

1. Populasi

Populasi dalam penelitian ini adalah semua ibu in partu yang ada di Puskesmas Mahalona sebanyak 32 orang periode Januari sampai April 2018.

2. Sampel

Sampel dalam penelitin ini adalah ibu yang in partu di Puskesmas Mahalona sebanyak 35 orang. Teknik pengambilan sampel menggunakan teknik secara total Sampling.

D. Instrumen Penelitian

Instrumen yang digunakan dalam penelitian ini adalah terstruktur dimana pengumpulan data telah menyiapkan instrument pertanyaan tertulis yang alternative jawabannyapun telah disiapkan.

E. Pengumpulan Data

1. Data Primer

Data primer disebut juga data tangan pertama. Data primer diperoleh langsung dari subjek penelitian dengan mengenakan alat pengukuran atau alat pengambilan data, langsung pada subjek sebagai sumber informasi yang dicari.

2. Data sekunder

Disebut juga data tangan kedua. Data sekunder adalah data yang diperoleh dari rekam medik.

F. Pengolahan dan Penyajian Data

Langkah-langkah pengolahan data secara manual pada umumnya melalui langkah-langkah sebagai berikut :

1) Editing (penyunting data)

Hasil wawancara atau angket yang diperoleh atau dikumpulkan melalui koesioner perlu disunting (edit) terlebih dahulu. Kalau ternyata masih ada data atau informasi yang tidak lengkap, dan tidak mungkin dilakukan wawancara ulang, maka kuesioner dikeluarkan (droup out).

2) Membuat lembaran kode (coding sheet) atau kartu kode (codin sheet)

Lembaran atau kartu kode adalah instrument berupa kolom-kolom untuk merekan data secara manual. Lembaran atau kartu kode berisi nomor responden dan nomor-nomor pertanyaan. 
3) Memasukkan data (data Entry)

Yakin mengisi kolom-kolom atau kotak-kotak lembar kode atau kartu kode sesuai dengan jawaban masing-masing pertanyaan.

4) Tabulasi

Yakin membuat table-tabel, sesuai dengan tujuan penelitian atau yang diinginkan oleh penelitian.

G. Analisis data

1. Analisis Univariat

Analisis univariat untuk mendapatkan gambaran distribusi frekuensi atau besarnya proporsi menurut berbagai karakteristik variabel yang diteliti baik untuk variabel bebas maupun variabel terikat.

2. Analisis Bivariat

Analisis ini digunakan untuk mengetahui hubungan antara dua variabel yaitu variabel bebas dan variabel terikat dengan menggunakan test kemaknaan berupa uji Chi-Square dengan derajat kepercayaan $95 \%(\alpha=, 05)$.

H. Etika penelitian

Penelitian ini dilakukan dengan memperhatikan etika meliputi:

1. Izin penelitian

Izin dilaksanakan sebelumnya penelitian mengajukan permohonan izin pada institusi penelitian dan melibatkan proposal riset.

2. Informed consent

Selanjutnya sebelum informed consent ditandatangai oleh semua partisipan. Peneliti menjelaskan judul riset, manfaatnya bagi subjek, sifat partisipasi (sukarela), kerahasiaan data, apa yang terjadi selama penelitian berlangsung. Prinsip ini tertuang dalam informed consend yaitu persetujuan untuk partisipasi sebagai subjek penelitian setelah mendapatkan penjelasan yang lengkap dan terbuka dari peneliti tentang keseluruhan penelitian.

3. Animity

Untuk menjamin kerahasian subjek peneliti tidak mencantumkan nama mereka (animity). Data akan disimpan dengan nama kode khusus nama subjek hanya diketahui peneliti atau masing-masing subjek bila mereka menginginkannya.

4. Confidentiality

Kepada subjek juga disampaikan bahwa segala informasi yang diberikan akan dijamin kerahasiaannya (Confidentiality) hanya akan diketahui oleh kelompok tertentu saja informasi tersebut akan peneliti sajikan, utamanya dilaporkan pada hasil riset. Setelah mereka setuju untuk berpartisipasi dalam riset ini semua partisipan diberikan bahwa mereka tetap saja mengundurkan diri dari penelitian kalaupun mereka menghendaki.

Mereka juga diberitahu jika selama proses pengumpulan data menyebabkan ketidaknyamanan emosional atau stress mereka dapat langsung menghentikan saat itu juga. Tujuan penelitian harus etik dalam arti hak responden dan yang lainnya harus dilindungi. 


\section{HASIL PENELITIAN}

Hasil pengolahan data telah dilakukan sesuai dengan tujuan penelitian maka penyajian data dilakukan sebagai berikut.

A. Analisis Univariat

1. Endorphin massase

Tabel 4.1

Distribusi Frekuensi endorphin massase terhadap rasa nyaman selama proses persalinan di Puskesmas Mahalona Kabupaten Luwu Timur tahun 2018

\begin{tabular}{|c|c|c|}
\hline \hline Endorphin massase & frekuensi & $(\%)$ \\
\hline Ya & 16 & 50 \\
Tidak & 16 & 50 \\
\hline Total & 32 & $100 \%$ \\
\hline
\end{tabular}

Sumber : Laporan Persalinan Puskesmas Mahalona tahun 2018

Tabel 4.1 menggambarkan bahwa dari 32 ibu bersalin terdapat 16 orang (50\%) yang di massase endorphin dan 16 orang (50\%) yang tidak di massase endorphin.

2. Rasa nyaman selama proses persalinan

Tabel 4.2

Distribusi Frekuensi rasa nyaman selama proses persalinan di Puskesmas Mahalona Kabupaten Luwu Timur tahun 2018

\begin{tabular}{|c|c|c|}
\hline \hline $\begin{array}{c}\text { Rasa nyaman selama proses } \\
\text { persalinan }\end{array}$ & frekuensi & $(\%)$ \\
\hline Ya & 19 & 59,4 \\
Tidak & 13 & 40,6 \\
\hline Total & 32 & $100 \%$ \\
\hline
\end{tabular}

Sumber : Laporan Persalinan Puskesmas Mahalona tahun 2018

Tabel 4.2 menggambarkan bahwa dari 32 ibu bersalin terdapat 19 orang $(59,4 \%)$ yang mengalami rasa nyaman selama proses persalinan dan terdapat 13 orang $(40,6)$ yang tidak memiliki rasa nyaman selama proses persalinan. 
B. Analisis Bivariat

1. Pengaruh endorphin massase terhaadap rasa nyaman selama proses persalinan

Tabel 4.3

Pengaruh endorphin massase terhaadap rasa nyaman selama proses persalinan di Puskesmas Mahalona tahun 2018

\begin{tabular}{|c|c|c|c|c|c|c|c|}
\hline \multirow{3}{*}{ Endorphin massase } & \multicolumn{4}{|c|}{$\begin{array}{c}\text { Rasa nyaman selama proses } \\
\text { persalinan }\end{array}$} & \multirow{2}{*}{\multicolumn{2}{|c|}{ Total }} & \multirow{3}{*}{ Value } \\
\hline & \multicolumn{2}{|c|}{$\mathrm{Ya}$} & \multicolumn{2}{|c|}{ Tidak } & & & \\
\hline & $\mathrm{N}$ & $\%$ & $\mathrm{~N}$ & $\%$ & $\mathrm{~N}$ & $\%$ & \\
\hline $\mathrm{Ya}$ & 15 & $46,9 \%$ & 1 & $3,14 \%$ & 16 & $50,0 \%$ & \multirow{3}{*}{$\begin{array}{l}P= \\
0.000\end{array}$} \\
\hline Tidak & 4 & $12,5 \%$ & 12 & $37,5 \%$ & 16 & $50,0 \%$ & \\
\hline Total & 19 & $59,4 \%$ & 13 & $40,6 \%$ & 32 & $100 \%$ & \\
\hline
\end{tabular}

\section{Uji Chi Square}

Pada tabel 4.3 diatas menunjukkan bahwa dari hasil uji statistik secara komputerisasi dengan menggunakan uji chi square didapat nilai $p$ adalah 0.000 dimana ada pengaruh endorphin massase terhadap rasa nyaman selama proses persalinan.

\section{PEMBAHASAN}

Pengaruh endorphin massase terhadap rasa nyaman selama proses persalinan. Berdasarkan tabel 4.3 pengaruh endorphin massase terhadap rasa nyaman selama proses persalinan. dari hasil uji Chi Square didapatkan nilai $p$ ( $p$ - value) adalah 0.000 dimana $>0.05$, hal ini berarti H0 ditolak dan Ha diterima artinya ada Pengaruh endorphin massase terhadap rasa nyaman selama proses persalinan.

Berdasarkan kondisi yang ditemukan selama proses persalinan didapatkan bahwa sebagian ibu yang dilakukan endorphin massase mengalami rasa nyaman selama proses persalinan, namun ada juga ibu yang dilakukan massase namun tidak mengalami rasa nyaman selama proses persalinan.

Endorphin massage adalah teknik sentuhan dan pijatan, teknik endorphin sangat penting bagi ibu hamil sebab teknik ini dapat membantu memberikan rasa tenang dan nyaman baik disaat menjelang maupun di saat proses persalinan akan berlangsung. Endorphin sebenarnya adalah sebuah zat di dalam tubuh yang memiliki sekali manfaat adalah gabungan dari endogenous dan morphine, yaitu zat yang merupakan unsure dari protein yang di produksi oleh sel-sl tubuh serta sistem saraf manusia.

Salah satu cara penatalaksanaan nonfarmakologis untuk mengurangi nyeri persalinan dengan endorphine massage. Endorphin Massage merupakan sebuah terapi sentuhan/pijatan ringan yang cukup penting diberikan pada wanita hamil, di waktu menjelang hingga saatnya melahirkan. Hal ini disebabkan karena pijatan merangsang tubuh untuk melepaskan senyawa Endorphin yang merupakan pereda rasa sakit dan dapat menciptakan perasaan nyaman. 


\section{KESIMPULAN DAN SARAN}

A. Kesimpulan

Berdasarkan hasil penelitian diambil kesimpulan ada pengaruh endorphin massase terhadap rasa nyaman selama proses persalinan yang dibuktikan dengan uji statistik chi square nilai $p$ adalah $0,000(p<0.05)$

B. Saran

1. Perlunya kerja sama petugas dan pasien sehingga endorphin massase dapat dilakukan sehingga hasilnya bisa dirasakan ibu.

2. Perlunya peningkatan penyuluhan agar program ini jauh lebih baik dari sebelumnya dan dapat ditingkatkan sehingga program ini terus dapat dilaksanakan.

\section{DAFTAR PUSTAKA}

Dwi. Asri., Clervo Cristine (2012). Asuhan Persalinan Normal. Yogyakarta: Nuha Medika.

Fauziah Siti, (2015). Keperawatan Maternitas. Jakarta: Prenadamedia Group.

Icemi. Sukarni., Wahyu, (2013). Buku Ajar Keperawatan Maternitas. Yogyakarta: Nuha Medika.

Indrayani.,Djami.U.E.Moudy, (2017). Update asuhan persalinan bayi dan bayi baru lahir. Jakarta: Trans Info Media.

Judha Mohamad., Sudarti., Afroh Fauziah (2018). Teori Pengukuran Nyeri \& Nyeri Persalinan. Yogyakarta : Nuha Medika.

Kartikasari (2016) Pengaruh Endorphin Massage Terhadap Penurunan Intensitas Nyeri Punggung Ibu Hamil. Jurnal.

Maryunani Anik (2010). Nyeri dalam persalinan teknik dan cara penanganannya. Jakarta: Trans Info Media.

Notoatmodjo Soekidjo. (2014). Metode Penelitian Kesehatan. Jakarta: Rineka cipta.

Novita. 2017. Jurnal. pengaruh teknik relaksasi nafas dalam trhadap respon nyeri pada ibu inpartu kala I fase aktif di Puskesmas Bahu Kota Manado. Vol.5. No.1

Noviyanti, 2016. jurnal. pengaruh terapi pijat terhadap pengurangan nyeri persalinan kala I fase aktif pada ibu bersalin vol. 2, no.1

Oxorn Harry \& Forte. R. William (2010). Ilmu Kebidanan Patologi \& Fisiologi Persalinan. Yogyakarta : ANDI

Prawirahardjo Sarwono. (2016). Ilmu Kebidanan. Jakarta : Bina Pustaka

Rukiah Yeyeh, dkk (2012). Asuhan Kebidanan II Persalinan. Jakarta: Trans Info Media

Sugiyono, (2016). Metode Penelitian Kuantitatif, Kualitatif Dan R Dan D, Bandung: Alfabeta.

Sulistyaningsih, (2012). Metode Penelitian Kebidanan Kuantitaif-Kualitatif, Yokyakarta: Graha Ilmu.

Susila, (2014). Metodologi Penelitian Cross Sectional Kedokteran dan Kesehatan. Klaten: Bossscript.

Tando Marie, (2016). Asuhan Kebidanan Persalinan dan Bayi Baru Lahir. Jakarta: In Media 